\title{
Is Suicide the Unforgivable Sin? Understanding Suicide, Stigma, and Salvation through Two Christian Perspectives
}

\section{John Potter}

Citation: Potter, John. 2021. Is Suicide the Unforgivable Sin? Understanding Suicide, Stigma, and Salvation through Two Christian Perspectives. Religions 12: 987. https://doi.org/10.3390/rel12110987

Academic Editor: Curtis Lehmann

Received: 18 August 2021

Accepted: 4 November 2021

Published: 11 November 2021

Publisher's Note: MDPI stays neutral with regard to jurisdictional claims in published maps and institutional affiliations.

Copyright: (C) 2021 by the author. Licensee MDPI, Basel, Switzerland. This article is an open access article distributed under the terms and conditions of the Creative Commons Attribution (CC BY) license (https:/ / creativecommons.org/licenses/by/ $4.0 /)$.
Department of Philosophy and Religion, Barton Community College, Fort Riley, KS 66442, USA; potterj@bartonccc.edu

\begin{abstract}
Is suicide the unforgivable sin? Most Western arguments against suicide stem from Christian arguments. Christianity has a long-standing position that suicide is morally wrong. However, on the issue of suicide and salvation, Christianity is divided. Debate, discussion, and interpretation through the centuries have led to two different positions. This result has divided the Christian community in multiple ways. These beliefs have likely impacted the level of stigma associated with suicide losses, suicide attempts, and suicide survivors within Christianity. The stigma of suicide can be lethal if it is not properly addressed. Stigma can easily push people away from caring communities of support and from God. This paper examines the two predominate Christian theological positions on suicide and highlights areas where stigma has hindered help, support, and care. Lowering the negative effects of suicidal stigma is a foundational piece of the solution for communities of faith to engage people at risk of suicide.
\end{abstract}

Keywords: suicide; religion; Christian; salvation; forgiveness; sin; stigma; repentance

\section{Introduction}

Over 703,000 people die by suicide each year, according to the World Health Organization (World Health Organization 2021, p. 1). Suicide is among the leading causes of death worldwide. More people are dying from suicide than to malaria, HIV / AIDS, breast cancer, natural disasters, or wars and homicide (World Health Organization 2021, p. 1). While these numbers are alarming, suicidal behavior is prevalent. For each reported suicide, there are more than twenty suicide attempts (World Health Organization 2014, p. 26). The United States of America is facing its own suicide crisis. According to the American Association of Suicidology, suicide claimed the lives of 47,511 people in 2019 (Drapeau and McIntosh 2020, p. 1). Once one comprehends the sheer magnitude of suicide, it is easy to see how it is a universal problem.

Christians view suicide as a destructive force that wreaks havoc and calamity in our world. Its impact is felt around the entire globe. Suicide is more than a public health crisis; it is often a cry for help. People seek help as they struggle over the loss of a loved one or even their own thoughts of suicide. Some people open the Bible as they look for support. People also seek out clergy to ask important questions of faith, belief, and practice. They bring tough questions that demand religious answers as grieving communities pursue peace and comfort.

This article specifically examines Christian theology and its beliefs on suicide. The intent is to provide a theological essay that reviews multiple Christian viewpoints and interpretations. Reflecting on the theology of suicide is vital to combating stigma and providing care. Mason identifies that reflecting "theologically on suicide is important because (1) Christians hold a spectrum of nuanced beliefs, (2) few denominations have a stated position on suicide, and (3) your theology affects what you do" (Mason 2015, p. 5). The article investigates why Christians believe that suicide is wrong, and it examines the two predominant Christian theological positions on whether suicide is truly the "unforgivable" sin. 
I share this article as a military chaplain, a Christian pastor, and a Protestant writer who views the Bible as the Word of God. I write from this point of view and from a desire that Christians see the Imago Dei in all people.

\section{Why Christians Believe Suicide Is Wrong}

A theological understanding is necessary to discuss the subject of suicide inside and outside the community of faith. Identifying and understanding the classic Judeo-Christian arguments against suicide is the proper starting point for people to comprehend how Christianity itself has examined the subject. These points are not recent interpretations of Scripture but firmly held tenets of the Christian faith that have been established since the outset of the original Christian community.

Christianity is strongly against suicide. It carries a proscription on self-destruction due to the core beliefs of how humanity was made and how that life is to be valued. God communicates through Scripture and biblical principles that suicide is not his will. People are made in a unique fashion that demands preservation. God's Word declares the sanctity of life and demands that all of humanity preserve it. Christians read the Bible and use it to identify that suicide is the wrong choice. It establishes a moral code to follow, lays out divine instruction, and lists several examples of people dealing with suicidal circumstances. While each Christian denomination can highlight their own beliefs against suicide, there are four core beliefs that most Christians use to reject suicide.

\subsection{Humanity Is Made in the Image of God}

Theologians normally call human uniqueness Imago Dei or the image of God. I define the image of God as the unique nature, status, and worth of all human beings. The term is a Scriptural designation for all of humanity since they are created by God. In Genesis 1, God announces his crowning work to the heavenly host: "Let Us make man in Our image, according to Our likeness" (Gen. 1:26). Here the Hebrew terms selem (image) and demut (likeness) are used (Brand et al. 2003, p. 806). The terms image and likeness are essentially interchangeable ideas in the common Hebrew literary style of parallelism (Brand et al. 2003, p. 806). This divine pronouncement establishes a bright line of distinction between the creation of the animal kingdom and humanity (Gen. 1:24-25; Gen.1:26-27). They are two separate acts of creation. God places the "breath of life" into humanity (Gen. 2:7). God, who is Spirit, places spirit into humanity. "God the Spirit breathes into life the souls of human persons" (Oden 2001b, p. 18). Christians believe human beings are formed in the likeness of the divine "Us", a representation of the Trinity (Gen. 1:26-27). Humans receive a "capacity for communion with God exceeding that of all other earthly creatures" (Oden 2001a, p. 23). Humankind uniquely enters life with the ability for interpersonal interaction with the divine. "God creates beings who are capable of creaturely goodness and thereby are also capable of reflecting the incomparable divine goodness" (Oden 2001a, p. 102). Humans are to reflect the holy and loving attributes of God. Scripture shares, "You shall be holy, for I am holy" (Lev. 19:2, 20:7, 20:26, 21:8; Exod. 19:6; 1 Pet. 1:16; 1 Thes. 4:7). As image-bearers, people are set apart for holy use and purpose. Noble writes, "Christians have an obligation to promote a human culture, one that reflects the goodness of creation, the uniqueness of human persons as image bearers, and Christ's love" (Noble 2021, p. 2).

Christians believe that suicide disregards the image of God that exists within every individual. The image of God includes both the "who" and "what" of humanity. Oden writes, "humanity is intended to participate in the blessed life" (Oden 2001b, p. 110). Self-destruction rejects the special status humanity has as God's stewards over the earth and it prevents future good works or action on God's behalf. It halts participation, care, and support for other people as God intended. Image-bearers are "made for union with God, communion with others, love of self, and care for the world" (McKnight 2007, p. 23). Christians view suicide as rejecting all of these unique abilities that only humans possess. 
Once human beings enter the creation story, they become God's earthly representative and the focal point of God's kingdom. Since humanity is made in God's image, every human being is worthy of love, honor, and respect. Every human life is inherently valuable. There is a transcendent human dignity in each individual. While God values all of creation, humans are set apart from the rest of creation, due to his unique will for us. Christians hold that people carry part of their Creator in them and are called to reflect that divine nature on Earth. Image bearers "are earth's divine representatives" (McKnight 2007, p. 19). We learn in the story of Scripture that this image is "cracked" like a mirror with the entry of sin (McKnight 2007, p. 19). Human beings still reflect the image of God but in a degraded capacity from the original state. While the entry of sin changed human nature, it did not erase what God established in humankind. Closson laments the fall from this image but rejoices in the redemption of Christ:

One of the tragic results of sin is that man no longer properly images God; the remnants of the image have been marred. The relationship with our Creator is broken, and redemptive history bears witness to man's inability to obey and honor God. But the glorious truth of the New Testament is that restoration is possible through Christ, the perfect image of God (Col. 1:15), whose redeeming work restores the image to repentant sinners and establishes them as co-heirs with Christ. (Closson 2016)

Christians believe that the image, while once distorted from the fall, can be restored and made right through Jesus, the Son of God. People are created to mirror the divine nature of God. These new characteristics can again reflect the brightness of God in "righteousness and holiness" (Eph. 4:24). Christians are called to be "conformed to the image" of Christ and will someday be "like Him" (Rom. 8:29; 1 John 3:2). All people still bear the original image of God, which cannot be erased. However, the Christian faith emphasizes that people should be drawn to God's grace and move into greater conformity with the Almighty. When Christians look into the faces of people, it is appropriate to imagine seeing a reflection of the divine in every single person because they are made in the Imago Dei, the image of God.

\subsection{Suicide Is Self-Murder}

Second, suicide is considered a violation of the commandment, "You shall not murder" (Exod. 20:13; Deut. 5:17). The prohibition against murder is found in the Ten Commandments, the heart of the Hebrew law (Exod. 20:13; Deut. 5:17). The statute is commonly identified as the fifth commandment for Roman Catholics, Lutherans, and Anglicans while most Protestant churches refer to it as the sixth commandment (Van Hooff 2000, p. 112). Murder is clearly identified as a sin in Scripture (Exod. 20:13; Deut. 5:17). Murder is the taking of life without legal or moral justification. ${ }^{1}$ There are many Hebrew and Greek words for kill, but the word used in the commandment specifically says murder (Strong 1996, p. 134). The Hebrew for this verb usually refers to a premeditated and deliberate act wherein one is slaughtered or dashed to pieces (Strong 1996, p. 134). Just as Cain slew his brother, there is an intent to end someone's life. Taking life in this manner is against God's law. Winslow shares, "If I am commanded not to shed the blood of another man because he is made in the image of God, I am not justified in shedding my own blood, as I stand in the same relation to the Deity as my fellow-men" (Winslow 1972, p. 37). Howsepian takes the same approach. Howsepian writes, "All murders are, after all, wrongful killings of certain sorts, namely, those wrongful killings that are constituted by one's intentionally bringing about the deaths of innocent persons" (Howsepian 1998, p. 300). Terminating life goes against the way of God. Howsepian speaks strongly on the matter:

It is immediately apparent from the OT that murder is unspeakably abhorrent for at least two reasons: (1) It is the irremedial and permanent destruction of life, the most precious possession an individual can ever have; (2) It is an assault upon God Himself, for every human being without exception is an image-bearer of his 
Creator ... There is not only inherent value in humanity-there is imputed value as well. (324)

Augustine's (1887) work position in the fourth century was, "the law, rightly interpreted, prohibits suicide, where it says, 'You shall not kill'" (bk. 1, ch. 20) and "no man ought to inflict on himself voluntary death ... for those who die by their own hand have no better life after death" (ch. 26) and "it is therefore wicked to kill oneself" (ch. 27). Mason (2015) shares how Augustine went beyond identifying suicide as a moral wrong.

In addition to using the sixth commandment, Augustine marshaled four other arguments against suicide: Christ never recommended it, Christians should live lives of faith and trust in God even in the midst of suffering, death cuts off the possibility of repentance, and suicide (a certain sin according to Augustine) should not be chosen instead of an uncertain sin, a sin which may not happen (like the rape of Pelagia, which is not certain to have occurred), and instead of a sin which is not one's own (because the rapist, not Pelagia, would own the guilt). (7)

Murder contradicts the priceless worth that God has placed in and on every human being. According to Christians, suicide is a subset of this commandment. It is ending your own life, or self-murder, as the Latin root of the word suggests (Van Hooff 1990, p. 255). Christians hold that the Bible is not mute on suicide because it is addressed as a prohibition against murder in the Ten Commandments. Suicide is viewed as the intentional taking of human life, even if the life taken is your own.

The purpose of the Ten Commandments or the law was first to show people God's perfect standard and the unchanging nature of God. It emphasizes prohibition of acts that Christians commonly identify as sin. The law also emphasizes vertical and horizontal relationships. Christians believe that their faith must be both vertical and horizontal. Vertical faith is their linkage with God, and horizontal faith encompasses their relationship with others. Horizontal faith also encompasses a relationship with yourself, since people are called to love their neighbor as they love themselves (Mark 12:28-31). The law should be followed out of respect for God and out of respect for humankind. Christians will also emphasize that obedience to the law is not just legal but out of love for Jesus. They believe that one should follow all of the commandments out of love toward others as well as toward self. God wants people to live beyond mere behavior and acts. God wants to create the kind of heart that generates good, righteous, and holy behavior. God does not merely want people to obey rules for the sake of obedience. God wants all of humanity to be holy as God is holy and to value what he values (Lev. 19:2, Lev. 20:7, 1 Pet. 1:16, 1 Thes. 4:7). Murder clearly goes against the values of God, and suicide falls into the same category. Since each life is precious and treasured by the Almighty, people should not practice suicide.

The prohibition against murder is so important for humanity that it is given to Noah and his family immediately after the flood. This likely predates the Exodus account by more than 1000 years. $^{2}$ The importance of this Scripture passage is often overlooked. It is important because God established tenets against shedding blood a century before the Ten Commandments were presented as the law for Israel. This makes the Genesis 9:6 prohibition of shedding human blood the original Talmudic perspective and position on suicide (Kaplan and Cantz 2017). Jewish teaching and Talmudic works identify any shed blood or any loss of human life as a violation of God's command. "The Talmudic tradition condemns suicide as a most heinous sin" (Kaplan and Cantz 2017, p. 41). Murder and suicide were already viewed as equal because these acts destroy the Imago Dei (Kaplan and Cantz 2017). The Hebrew Bible describes God as a kind creator who forms human beings in the "divine image" (Kaplan and Schwartz 2008, p. 36). The Jewish view of creation and the image of God are intertwined. "To murder oneself or another is a grevious degradation of life" (Kaplan and Schwartz 2008, p. 36). Many Judeo-Christian theologians continue to hold this position today (Mason 2015). 
Here, God reminds humanity that they are made in his image and are valuable in his sight and that they are to honor the sanctity of human life. The prohibition against murder serves as a hedge to protect human dignity. God's high regard for life means that murder will not be tolerated. The covenant with Noah emphasizes a new beginning and a divine promise never to destroy earthly life with a flood (Gen. 9:9-11). Part of this new beginning points back to the Garden and reminds people of their own worth: "Whoever sheds man's blood, by man his blood shall be shed, for in the image of God He made man" (Gen. 9:6). ${ }^{3}$ Some may look at this verse and say that it is cold and uncaring or that it institutes capital punishment on the Earth. God gives this edict as a way to save and preserve life, not to take it. Christians propose that all people are precious and valued in the sight of God. Christians hold that humans are all unique and beyond price. Life has absolute value, and if it is violated with spilt blood, then there is a penalty for violating its sanctity. This understanding also holds that a murderer demonstrates contempt for God and for all of humanity, not for just his or her victim. Spilling blood is clearly identified as wrong action and goes against the new beginning God provided to Noah and his descendants. Ending your own life by suicide is a category of murder. Scripture defines murder as the premeditated destruction of life; therefore, suicide as a premeditated self-killing is a category of murder (Merrill 1998, pp. 315-16).

\subsection{Our Lives Belong to God}

Third, God is the owner and giver of life. Scripture points out that we are not our own but stewards of a life that God has given (Jer. 10:23). Life is a precious gift, and it is not to be thrown away or abandoned. Christians believe in a sovereign and supreme God. If God is the Lord of all that is, then he retains ownership over our lives and all of our days. God is the only one who can determine when our service is complete and our intended purpose fulfilled. Christians hold that since they belong to God, then life is not something to be thrown away. One should view life as sacred and precious. Noble argues, "A proper understanding of our personhood requires we recognize that we are not our own" (2021, p. 5). Noble writes that this idea goes beyond personal validation or identity. There is no need for existential validation because our existence is already considered good through our belonging to Christ (Noble 2021, p. 131). Scripture teaches that human lives belong to the Creator and that people are not to end life for their own purposes, no matter how distraught or hopeless one might feel. The life one has, specifically belongs to God. In good times and in difficulty, people are called to honor God with their life.

Job had several catastrophes befall him and his family. Hearing the news of these personal atrocities, Job utters, "Naked I came from my mother's womb, and naked I shall return there. The Lord gave and the Lord has taken away. Blessed be the name of the Lord" (Job 1:21). In all of the heart-wrenching hurt and drama, Job did not sin or blame God (Job 1:22). He is deeply grieved and appears to have suicidal thoughts of strangling himself (Job 7:15). However, Job does not act on this. As the story proceeds, Job reaffirms his relationship with his Creator: "Though He slay me, yet will I trust in Him ...." (Job 13:15). Job was able to argue within the relationship he had with God without leaving it. Christian theology amplifies this point of Scripture. Job understood that his life did not belong to him but to God. God breathes life into us (Gen. 2:7), and it is God who takes it away (Job 34:13-15). The example of Job is powerful and instructive. Just like Job, people can also choose to keep living even through difficult circumstances.

The story of Job is about the goodness of God even in the midst of human suffering and calamity. According to Christian doctrine, we do not earn merit with good works, nor do we lose favor from a lack of obedience. God cannot be reduced to a transactional relationship, like putting coins into a vending machine. God does not award points based on a person's good behavior. A simple reading of Job elicits the humanity of the story. A deeper reading plumbs the theological richness of God's sovereignty and prerogative in life and death. This is shown especially in the conversations between Job and his friends. Despite the trials and tribulations of Job, he refused to take his own life. 
The Christian perspective is not that life is without trials or hardship. It holds that no one is exempt from human suffering, but that everyone is called to remain and continue as faithful servants, no matter the current trials of life (Matt. 24:13, Heb. 10:36, James 1:12). Christians firmly believe that we do not belong to ourselves. Our lives are in the hands of God, who has a plan, a purpose, and a reason for us to exist, even if at times people forget these scriptural truths.

Paul wrote to the Corinthian church and reminded them that the body belongs to the Lord (1 Cor. 6:19-20). While some in the Corinthian community may have felt they had a right to do as they please, Paul argued that total freedom of action may not benefit the believer. What one does with the physical body is important because God has regard for this earthly vessel. Paul reminded the church that a body destined for resurrection should not be used for immorality (1 Cor. 6:14). It is not merely the spirit that is a member of Christ but the whole person, consisting of spirit and physical body. Since the body is so precious to God, nothing should be done to harm it. There are immoral actions outside the body and internally; nevertheless, the body is a sacred place where God dwells. Paul asks, "Or do you not know that your body is a temple of the Holy Spirit who is in you, whom you have from God, and that you are not your own? For you have been bought with a price: therefore, glorify God in your body" (1 Cor. 6:19-20). Paul was concerned with more than the use and misuse of the body. He was concerned with how people relate to God.

\subsection{Suicide Harms Community}

The final reason Christianity does not condone suicide is that suicide is seen as harming the entire community, not just the individual. It injures those around us and even far beyond. Hauerwas writes that "One should not commit suicide because of one's duty to others in the community. People should not be viewed as atomistic individuals who are unconnected to others" (Hauerwas 1998, p. 190). This addresses our horizontal relationship of faith. Christians strongly believe that they are called to love and care for those around them. In Mark's gospel, Jesus is asked to name the most important or the greatest commandment. He gives two responses, "And you shall love the Lord your God with all your heart, and with all your soul, and with all your mind, and with all your strength. The second is this, you shall love your neighbor as yourself. There is no commandment greater than these" (Mark 12:30-31). Jesus pointed to Deuteronomy 6:4-5 and Leviticus 19:18, two very important passages. Jesus combined the two Old Testament passages to show that the love of neighbor is a natural outgrowth of the love for God. The horizontal and vertical are deeply connected. Typically, when one hears the second commandment, people reflect on the need to think more highly of others because of a great love of self. Our pride, self-confidence, and inflated egos have gotten in the way of loving others; we overly prize ourselves. Of course, such narcissistic characteristics are contrary to loving others, as we are to love ourselves as well as them. However, the opposite is also true in this passage. Our sorrow, despair, despondence, and depression can show how little we love ourselves. We can have a self-attitude that is too small. The commandment shows that we must properly love self and then share that love with our neighbor. Again, Jesus shows the importance of connecting the love of God and the love of neighbor. It means loving yourself and also sharing that love with the entire community.

The community is large and complex and has many parts. While community is often touted in the routine categories of family, friends, and neighbors, Scripture calls the family of God to love people outside of these comfortable and familiar circles. Christian principles emphasize the call to love difficult people, not just those you might treasure. Christians are even called upon to love their enemies and pray for those who persecute them (Matt. 5:44). The community is much larger than one may imagine. Paul points out, "There is one body, but it has many parts" (1 Cor. 12:12). A hand is different from a foot. An ear is different from an eye. One part of the body cannot be any less because it is different. These different parts are necessary for the entire body. The whole body cannot be an eye. It is necessary for the entire body parts to function together. Many parts, pieces, and members 
are required for the body to work. God has placed the members together in the body, just as he desired. It is not our place to call one out and say that there is no need for a particular part. Instead, there should be no division in the body, and the members should "have the same care for one another" (1 Cor. 12:25). The community needs each part in the body, each person that God has given. Suicide injures more than the individual; it harms the entire community. A recent study concluded that one suicide results in 135 people being exposed to the event (Cerel et al. 2018). The exposure of suicide became a heavy burden that people carry when friends and family are forced to deal with the sudden loss of a loved one. Suicide leaves an enormous hole in homes, families, congregations, and our society that was never intended. Christians point out that God's plan would avoid this injury, pain, and suffering for communities.

\subsection{Interpretations of Suicide in the Bible}

Academics, historians, and theologians do not agree on when the Christian Church first taught on suicide. What does seem clear, though, is that the message about suicide changed over the centuries, gradually becoming more condemning. According to Van Hooff (2000), "In its early stages the Church had not been very outspoken on selfkilling. Christians were exhorted to prevent their brethren from getting so desperate that they killed themselves. Thus, the approach was pastoral rather than condemning" (107). Sheldrake (2007) writes that "Christianity continually confronted hostility and active persecution in the public arena until the edict of tolerance under the Emperor Constantine (313). Inevitably this gave rise to a spirituality of martyrdom related very strongly to identification with the passion of Christ" (24). Some point to this time of Christian acceptance and rising dominance as the moment when Christians sought to unify teaching against suicide. Clemons (1990) believes early Christianity viewed suicide as acceptable martyrdom up until the prohibitions written by Augustine (78-79). Specifically, Clemons (1990) argues that Augustine attacks the matter of suicide so harshly because of "rampant suicide among Christians" (79). The actions of Augustine were intended as a counterbalance to quiet heretical movements and stop those using self-killing to pursue martyrdom (79). As Christianity grew into the dominant religion of the Roman Empire, suicide was labeled a sin and a secular crime.

One author identifies a progression toward this consolidation. "In the fourth century, when the Church became dominant, the principled rejection of suicide took shape, Lactantius (ca. 250-ca. 320) put self-killing on par with manslaughter: 'For if a homicide is abominable because he is a destructor of man, he falls under the same crime as one who kills himself, for he kills a man' (Divinae Institutiones III, 18)" (Van Hooff 2000, p. 107). Here Van Hooff suggests there was an incremental movement. "The definitive doctrine was laid down by St. Augustine (354-430), who has always been the main authority for Christendom in the West" (Van Hooff 2000, p. 107). It is believed that Augustine's writing in The City of God is the first to explain the commandment "Thou shalt not kill" as meaning "neither another nor oneself" (Van Hooff 2000, p. 107).

Others believe that the positions against self-killing were already present within the Christian community and emphasized in their teachings. Hsu believes that the biblical accounts of suicide provide enough weight and force for Christians to view and interpret suicide negatively from the very start. Each story is enough to see how suicide is portrayed. The biblical narrative shows that "Suicide is never held up positively in Scripture. There are seven suicides in Scripture from King Saul to Judas, and they're always depicted negatively. They are never God's plan for anybody's life." (Hsu 2017).

Keener agrees that first-century teachings would interpret suicide as a moral wrong and a highly negative act. He writes that Judas's suicide is an act of despair, but it would not be viewed well within Judaism. "Greco-Roman tradition considered suicide a nobler way to die than letting others kill one. To some Jewish people it was likewise noble if it was performed to avoid falling into the hands of torturers or to avoid being defiled. However, Judaism, especially strict Palestinian Judaism, normally regarded it 
as evil" (Keener 1993, pp. 124-25). Keener suggests that this Jewish understanding of suicide being morally objectionable would automatically spill over to the followers of Jesus and Christianity because it is the default concept of the religious community. Their Jewish perspective and interpretation of Scripture should be added and considered in the discussion.

Kaplan and Cantz also share this point of view. They argue that one needs to fully understand the Talmudic perspective of suicide because it is such a stark contrast to the Greco-Roman perspective of that era. The society of the Greeks and Romans offered a worldview that openly permitted and even glorified suicide. It was considered a noble or good death in that era (Van Hooff 2000, p. 103). Kaplan and Cantz (2017) assert that "No Talmudic passage can be taken as praising suicide or glorifying heroism in the Greek sense, nor is there an obsession with death as the solution to life's problems or with the issue of control" (70). Kaplan and Cantz also point out the following:

It is obviously incorrect, then, to claim that there are no suicides in biblical and later Jewish history. Individual suicides have occurred despite the injunctions against them. Nevertheless, suicide is strongly prohibited in biblical and later Jewish thought, and when it has appeared within the culture, it may represent individual idiosyncrasies, impossible external situations, or profound GrecoRoman influences. The basic Jewish preference for life over death as expressed in the Hebrew Bible has never changed, nor has suicide ever been idealized as an end in itself. (71)

More importantly, they write, "The biblical basis for the Jewish injunction against suicide has been derived from the Noahide laws: 'For your lifeblood too, I will require a reckoning' (Genesis 9:5)" (Kaplan and Cantz 2017, p. 42). Here, Judaism places the issue of suicide in terms of life and death. Jews firmly hold that the Torah passages of Genesis 9 and rabbinic laws are prohibitions against suicide (Kaplan and Cantz 2017, p. 43).

The Talmudic prohibitions are the exact concerns that Christian theology points out in the Old Testament today. These core beliefs on suicide are shared in both faith groups. Kaplan and Cantz write that even the fall of Masada, where a mass suicide took place during the Roman siege, should be seen with this lens. "Although Masada has become a symbol of bravery in much of the modern world, its lesson for Israel is that Masada must not fall again, rather than the aggrandizement of suicide" (70). Ignoring the Jewish perspective on suicide can only weaken or conceal a scriptural understanding on the subject.

O'Mathuna writes that moral instruction and ethical behavior have long been used as teaching techniques within the Jewish and Christian communities. He argues that the biblical accounts of suicide "support the long-standing Christian position that suicide is morally wrong" (O'Mathuna 1998, p. 350). It should not be viewed as a new construct from the third or fourth centuries. "The Old Testament records events for our instruction (1 Cor 10:11). But it frequently does so through narratives (i.e., stories), not abstract philosophy. Not enough attention has been given 'to the problem of how to extract moral principles from biblical writers who did not usually present their thoughts in abstract terms'" (O'Mathuna 1998, p. 351). Biblical narratives show us ethics in action and the character of people. Sometimes we find godly character, sometimes ungodly. Even Jesus used parables and stories as teaching tools to share moral lessons (Matt. 13:3, Luke 15:3). "Problems arise when readers of the Bible fail to distinguish between God's view of what is right and 'descriptive sections of poor human responses to the lofty claims and challenges of the divine'" (O'Mathuna 1998, p. 351). O'Mathuna argues that the religious teachings against suicide are present in Scripture and have been used to teach that position since the texts were established.

The timing of these Judeo-Christian teachings on suicide matters. If one argues that Scripture originally makes the argument against suicide, then the edict comes directly from God. Scriptural teaching is authoritative because it comes from God. Scripture is to be considered timeless, holy, sacred, and true. A righteous and holy standard that humanity should not ignore. If one argues that the teaching is a new matter of interpretation 
from Lactantius or Augustine, then the matter comes from a human instead of the Holy One. There is no transcendent or divine authority behind it unless it is anchored to Scripture. The teaching could easily become a fluid matter. Here people are free to pick and choose the teachings they want to follow. Suicide could then be viewed as merely a subject of biblical interpretation and easily become a moving target instead of a firm moral precept of the Church. One could make the argument that Paul was suicidal while writing to the Philippians from prison (Croy 2003). One could also make the argument that the death of Jesus was a suicide or an assisted suicide if there is no authoritative connection to Scripture (Cooley 2020). If Christian teachings on suicide are only tethered to denominational statements and position papers instead of Scripture, they can easily be amended or changed at yearly assemblies. Mason's 2015 work Developing a Christian Theology of Suicide identifies multiple positions that Christians can argue across the vast spectrum of thought regarding suicide.

While scholars do not agree on the exact timeline of when these biblical beliefs were established, almost every branch of Judaism and Christianity agrees that these core values underpin their faith and interpretation of Scripture regarding suicide (Campbell 1992). These four biblical principles and concepts have resulted in a longstanding Judeo-Christian belief that suicide is wrong. The call to preserve life through a prohibition on murder is found in multiple sections throughout the Old Testament. The moral perspectives of how to view people are also foundational to Christian beliefs. Christians are called to see value in others and share the love of God as a lifestyle that demonstrates the kingdom of God.

\section{Suicide and Salvation}

The theological issue of suicide and salvation can be divided into two predominant Christian perspectives. One group believes that suicide is a mortal sin that sends people to Hell. The mortal sin position is found in the Roman Catholic Church. The second group believes that suicide is a sin but does not elevate one sin above another. All sins are equally offensive to God, but they are all capable of being forgiven through the atoning sacrifice of Jesus. This is the predominant view of evangelical Christians and most of the Protestant community. Roman Catholic creeds, statements of faith, and historical perspectives are used to examine their theology. Creedal statements or a catechism are not used in the Protestant section because of the furcated nature it would take in Protestant circles. There are many different branches within the Protestant community. For instance, some groups may recognize the Heidelberg Catechism of 1563 while other Protestants may not agree with it or use it within their denomination. Scripture is used to establish the Protestant position because it is universally accepted. This group believes in the authority of Scripture and uses the Bible to establish their positions of faith and practice. Since Scripture is considered authoritative, it is the focus through which to examine their theology.

\subsection{The Roman Catholic Approach}

The Roman Catholic Church views suicide as a mortal sin, maintaining a distinction between mortal and venial sins. The former separates a person from God's grace; the latter, while serious, does not. Mortal sin is considered a serious offense that merits eternal damnation if not repented and forgiven before death. The Catechism of the Catholic Church (CCC) states:

Mortal sin is a radical possibility of human freedom, as is love itself. It results in the loss of charity and the privation of sanctifying grace, that is, of the state of grace. If it is not redeemed by repentance and God's forgiveness, it causes exclusion from Christ's kingdom and the eternal death of hell, for our freedom has the power to make choices forever, with no turning back. However, although we can judge that an act is in itself a grave offense, we must entrust judgment of persons to the justice and mercy of God. ( 1861)

Here, Roman Catholics express that "Sins are rightly evaluated according to their gravity. The distinction between mortal and venial sin, already evident in Scripture, became 
part of the tradition of the Church" (Catechism of the Catholic Church 2019, 1854). Mortal sins are those of a grave offense and are "committed with full knowledge and deliberate consent" (Catechism of the Catholic Church 2019, 1857). The grave offenses are specified by the Ten Commandments, chief among them, the prohibition on murder (Catechism of the Catholic Church 2019, 1858).

The Catechism of the Catholic Church believes that venial sins are offenses, but they are offenses not established by the mortal law. Hence, venial sins do not sever a believer's relationship with God, remove you from a state of grace, or jeopardize one's eternal salvation.

Venial sin weakens charity; it manifests a disordered affection for created goods; it impedes the soul's progress in the exercise of the virtues and the practice of the moral good; it merits temporal punishment. Deliberate and unrepented venial sin disposes us little by little to commit mortal sin. However venial sin does not set us in direct opposition to the will and friendship of God; it does not break the covenant with God. With God's grace it is humanly reparable. Venial sin does not deprive the sinner of sanctifying grace, friendship with God, charity, and consequently eternal happiness. (Catechism of the Catholic Church 2019, 1863)

This creates a system of major and minor offenses within Catholicism. It also creates a framework where living in a "state of grace" is a moving target for the believer. Here, it is a daily struggle to stay in the good graces of God. God's complete and total forgiveness for an individual is conditional and requires repentance for mortal sin to be absolved. The Roman Catholic position expresses that deliberately taking your own life without repentance incurs eternal damnation.

Roman Catholics who received their religious formation and or attended a Catholic school before 1965 were taught the Baltimore Catechism (Kehoe 1998). This part of their religious education "consisted of memorizing the Baltimore Catechism with its questionand-answer format" (Kehoe 1998, p. 215). After the Second Vatican Council was fully implemented throughout Roman Catholic institutions across the world, "the Baltimore Catechism was no longer the main tool for communicating Catholic doctrine" (Kehoe 1998, p. 217). Catholics raised with the Baltimore Catechism were taught that suicide is a mortal sin because it is an act against the will of God and a violation of the fifth commandment. Most Protestants count the edict against murder as the sixth commandment, while Roman Catholics count it as the fifth. The Baltimore Catechism asks, "What sin is it to destroy one's own life, or commit suicide, as this act is called?" The catechism answer is, "It is a mortal sin to destroy one's own life or commit suicide, as this act is called, and persons who willfully and knowingly commit such an act die in a state of mortal sin and are deprived of Christian burial. It is also wrong to expose oneself unnecessarily to the danger of death by rash or foolhardy feats of daring" (Baltimore Catechism 1891, 1274). Catholics used Scripture, different forms of catechism, and tradition to teach that suicide costs someone his or her salvation. While this teaching has not exactly changed, it has become more nuanced regarding mental illness.

A person who willfully and knowingly chooses suicide would still be considered to be in a state of mortal sin, not a state of grace. The Roman Catholic Church acknowledges, however, that many people who die by suicide suffer from mental illness and may not be capable of making a clear or rational decision. This was first reflected in 1992 when John Paul II approved a change to the Catechism of the Catholic Church. This newly articulated position represents a major move for the Roman Catholic stance on suicide. The Catechism of the Catholic Church (2019) even highlights the 1992 portion by setting it apart from the original section in statement 2282:

\section{Suicide}

2280 Everyone is responsible for his life before God who has given it to him. It is God who remains the sovereign Master of life. We are obliged to accept life gratefully and preserve it for his honor and the salvation of our souls. We 
are stewards, not owners, of the life God has entrusted to us. It is not ours to dispose of.

2281 Suicide contradicts the natural inclination of the human being to preserve and perpetuate his life. It is gravely contrary to the just love of self. It likewise offends love of neighbor because it unjustly breaks the ties of solidarity with family, nation, and other human societies to which we continue to have obligations. Suicide is contrary to love for the living God.

2282 If suicide is committed with the intention of setting an example, especially to the young, it also takes on the gravity of scandal. Voluntary co-operation in suicide is contrary to the moral law.

Grave psychological disturbances, anguish, or grave fear of hardship, suffering, or torture can diminish the responsibility of the one committing suicide.

2283 We should not despair of the eternal salvation of persons who have taken their own lives. By ways known to him alone, God can provide the opportunity for salutary repentance. The Church prays for persons who have taken their own lives. (Catechism of the Catholic Church 2019)

The catechism affirms that suicide is contrary to both love of God and love of self and that it goes against the basic human instinct to preserve life. However, it also notes that "Grave psychological disturbances, anguish, or grave fear of hardship, suffering, or torture can diminish the responsibility of the one committing suicide" (2282). While the 1992 change does not erase the Roman Catholic position on suicide being a mortal sin that undoes salvation, it certainly acknowledges that God is the final Judge who is able to show grace and compassion. It opens a door that had previously been shut for centuries. This new understanding establishes a bright line showing a moral difference between volitional suicide and suicide due to psychological factors. Here, the theology of the Church has shifted to view mental illness as a biochemical reality of our fallen nature. More denominations within the Christian faith are beginning to embrace this position (Lund 2014, pp. 96-97) and incorporate it into their concept of the Imago Dei.

The catechism also emphasizes that the church should pray for those who die by suicide and should not fear for their eternal salvation. This addition captures the idea that there is ultimately no telling if the person might have repented split seconds before death. The last catechism statement on suicide also encourages believers with, "We should not despair of the eternal salvation of persons who have taken their own lives. By ways known to him alone, God can provide the opportunity for salutary repentance" (2283). Catholics believe that all sins must be confessed to regain the grace of God, since it is lost by $\sin$. Catholics must confess venial sins and mortal sins to receive reconciliation with God and the church. In their view, an unconfessed mortal sin could potentially change one's eternal home due to the grave nature of the offense. In the case of suicide, Catholics advance the possibility that in the process of dying one might regret his or her action and repent of it, calling for God's mercy. As Church doctrine subscribes to the notion of God's omnipresence, his presence in every place and time, Christians would say that God is constantly "present" with us. This understanding means that God can transcend time. Therefore, it is possible for his grace to be extended even in the moments just before death. Monsignor Pope (2018) explains that in dying, there are some obvious physical qualities, but there is also latitude for some mysterious aspects related to the spirit's full departure to the judgment seat of Christ. Pope says, "It is to these mysteries that the Catechism refers. The same could be said for those who die suddenly. There may be some moments after physical death, but prior to the soul's departure where repentance is still possible" (2018). Salutary repentance is something that only God can give. The how is not known or even taught by the Church. The matter of repentance has moved beyond the physicality of this world and now rests in the hands of God. Did the suicidal person willfully separate himself or herself from God by his or her own free choice? Jesus will see the truth of the matter and judge accordingly. 
The Roman Catholic position on salutary repentance and the Almighty's ultimate sovereignty leaves room for God to act with grace and mercy as the final judge. While repentance must be sought prior to death or in the process of one dying, it still gives room for God's grace to be shared up until the very moment of death. Repentance cannot be sought after one's earthly life has ended, but salutary repentance places God above any religious rulebook, policy, practice, or canon law. It also points out that clergy must never condemn a victim of suicide to Hell but always have hope in the power of God's mercy. God alone knows the depth of each person. Salutary repentance also establishes a theological position where God would never allow a person to perish without the full benefit of his mercy. While the Roman Catholic teachings on mortal sin are firmly established in catechisms, canon law, creeds, policies, and more, there is very little teaching on salutary repentance. This is likely due to the unknown nature of any individual's final conversation with God. We have no ability to know what transpires and if one truly asks for repentance.

\subsection{The Protestant Approach}

Many Evangelical Christians and most Protestants do not believe it is possible for a Christian to lose his or her salvation, even if that person dies by suicide (Mason 2015). Yes, suicide is a sin among many sins, but it does not cast one away from the atoning work of Jesus. This camp makes no distinction or division on sin. One sin is not weighted above another. The sin of suicide cannot be excluded or divided into another category because there is only one category. The Protestant position also takes the view that even after regeneration, the moment of salvation, a Christian is capable of committing any sin. A Christian could even take the life of someone else, as Moses and David did, without this action invalidating their salvation. Protestants believe that the sacrificial atonement of Jesus is made by his death on the cross. This action has forgiven all of their sins-past, present, and future (Heb. 10:11-18). This one offering makes them clean through the blood of Jesus, as stated in Hebrews: "For by one offering He has perfected for all time those who are sanctified" (10:14). It is the fulfillment of Jeremiah 31:34 when God declares, "And their sins and their lawless deeds I will remember no more." The sin a Christian commits tomorrow was already forgiven at the cross of Christ. Jesus justifies the believer, making people positionally righteous (Rom. 3:23-26; 8:29-30). The Protestant believes that Jesus' death is capable of forgiving any sin.

Protestants also point out that a Christian is forever a child of God. Eternal life is bestowed at the moment of acceptance. As Jesus said, people are born again, enabling entry to see and partake in the kingdom of God (John 3:3). Immortality is in the present tense. It is right now. This is unlike the Roman Catholic position, which claims that one can forfeit their salvation or that the Holy Spirit somehow leaves the human body with the commission of suicide. The Bible shares, "I write these things to you who believe in the name of the Son of God so that you may know that you have eternal life" (1 John 5:13). Christians become subjects in the kingdom of God. They are on Earth but are partakers of the eternal life that Christ proclaims. They are part of the family of God, as declared in John 3:16: "For God so loved the world, that He gave His only begotten Son, that whoever believes in him shall not perish, but have eternal life." They become a new creation, one that will live on in union with God. Jesus said, "I am the resurrection and the life; he who believes in Me will live even if he dies, and everyone who lives and believes in Me will never die" (John 11:25-26).

Lastly, suicide is not the unforgivable sin that separates Christians from God. Those who die by suicide do not automatically go to Hell because of the act. Protestants balk at this idea because it creates a transactional view of sin and forgiveness, one where forgiveness is earned or received by one's own meritorious acts. Protestants believe that the idea of a Christian going to Hell because of suicide would mean that his or her salvation was a work undone by the act of suicide. This concept is totally foreign for Protestants. This would mean that suicide somehow becomes stronger than the death and resurrection of Jesus Christ. No verse of Scripture cancels the atonement of Jesus. No verse of Scripture 
connects suicide with one's eternal destiny. Protestants believe that if this act could cause us to lose our salvation, then the Bible would make that clear. For them, a believer cannot earn or lose salvation by human actions. Suicide does not separate the believer from the Savior. Grace and mercy cannot be earned by any earthly actions, as stated in Ephesians: "For by grace you have been saved through faith; and that not of yourselves, it is the gift of God; not as a result of works, so that no one may boast" (2:8-9). Meritorious works do not save a person, nor do poor works condemn a person for all of eternity. Wrong acts, deeds, and works cannot cancel the salvation one is offered in Christ. Human actions do not cancel positional righteousness, the righteousness people receive from God through Christ. The Bible shares that once a person is in Christ, nothing can separate that individual from him (Rom. 8:35-39). Protestants believe that once someone becomes a Christian, God will always be their Father. If they ask Jesus Christ to be their Lord, nothing can take them from his hand (John 10:28). The unpardonable sin is rejecting the Holy Spirit's offer of salvation and dying in a state of that rejection (Matt. 12:31). It is refusing the only pardon God is able to give. The act of suicide is not the unforgivable sin and does not cancel one's salvation in Jesus Christ.

\section{Christianity and Stigma}

There is little doubt that Christianity has contributed to the stigma of suicide. As Christianity grew from a persecuted faith into the dominant religion of the Roman Empire, suicide moved from the solitary status of a sin within the confines of the church and into a secular crime. The religious understanding of suicide as self-murder, unfortunately, changed into the civic condemnation of suicide. The biblical statements on suicide which were meant as a way to preserve and promote the sanctity of life declined into legalized acts of cruelty toward suicidal people and their families. Ramsay et al. (2004) share, "In the Middle Ages, the criminalization of suicide was at its worst. The bodies of people who killed themselves were dragged through the streets, hung naked upside-down for public view, and impaled on a stake at a public crossroad" (20). Families were also impacted by these events. The widow or widower and children "were formally censured, the family's property was confiscated, and the body was denied burial in the church or city cemetery" (Ramsay et al. 2004, p. 21). Some civil penalties still exist in countries today. The World Health Organization reports that out of 192 independent countries and states investigated, twenty-five have "specific laws and punishments for attempted suicide." (World Health Organization 2014, p. 51). Penalties in these nations range from a small fine to short-term imprisonment to a life sentence in prison (World Health Organization 2014, p. 51).

Church law for many Christian denominations prohibited full Christian funerals and burials for people who died by suicide. Adeogun reports that the Church of England formally ended the ban on full Christian funerals in 2017. He also writes that "Up until the 19th century the Church refused to offer Christian funerals for people who had committed suicide with a 'sound mind' or for those who hadn't been baptised. This was updated in the 1880 s to permit priests to bury those who had taken their own life but without the standard service set out in the Anglican Book of Common Prayer." (Adeogun 2017). In earlier times, the Roman Catholic Church followed the same practice. It was not until recently that the Roman Catholic Church allowed parishioners who had taken their own lives to receive a Catholic funeral and be buried in Catholic cemeteries. Today, Canon law no longer mentions suicide as an impediment to funeral rites or religious burial (Alessi 2014). Furthermore, as previously mentioned, Pope John Paul II made the historic change to the Catechism of the Catholic Church on how it views mental illness and suicide. It is only recently and with a heightened understanding of mental illness that many Christian positions have softened (Lund 2014; Simpson 2013). The trend is encouraging, but there is more room for Christianity to combat the stigma of suicide. 


\subsection{Reducing Suicidal Stigma through Connection}

Christian congregations are in a position to combat stigma and suicide because they provide supportive and integrative communities (Idler and George 1998). Much of today's language on suicide prevention focuses on the importance of promoting connection or connectedness. For instance, the CDC's 2017 policy paper on suicide prevention identifies multiple benefits that faith communities may offer. The publication argues that "Connectedness is the degree to which an individual or group of individuals are socially close, interrelated, or share resources with others" (Stone et al. 2017, p. 27). The policy paper identifies multiple levels of social ecology such as peers, neighbors, co-workers, families, and faith communities as ideal places for connection. The paper also says, "Connectedness and social capital together may protect against suicidal behavior by decreasing isolation, encouraging adaptive coping behaviors, and by increasing belongingness, personal value, and work, to help build resilience in the face of adversity" (Stone et al. 2017, p. 27). Connection allows people to see and know that they are not alone. Congregations are perfectly suited to provide this reminder. Congregations can also deliver messages of love, value, importance, and self-worth for those who are down or despondent (Stack 2018; Post 1998; Koenig 2012).

Christianity teaches that humans are alienated from God and that our needs, desires, and loves have become disordered (Johnson 2017). Johnson writes, "Consequently, their greatest need is to be restored to the way of life for which they were created-but that restoration is beyond their own abilities" (Johnson 2017, p. 19). Churches and communities of faith can function as connection factories in any neighborhood. Johnson indicates that it is God's intention for Christians to be earthly ambassadors who demonstrate love for all of humanity:

Local churches serve as images of the Trinity, being sites of relational healing and strengthening in the Spirit. As Christians grow in the knowledge and love of God, they become more equipped to love, encourage, comfort, admonish, and support other Christians in the communion they share with the Father and the Son (1 John 1:3) and so contribute increasingly and reciprocally to the "growth of the body for the building up of itself in love" (Eph. 4:16). (Johnson 2017, p. 68)

Religious involvement and practice have already been identified as protective factors that preserve life. Religious belief and activity are strong factors to keep people from suicide (Lester 2017). Wu and his colleagues showed a 71\% protective benefit of religion and spirituality within Western traditions (Wu et al. 2015, p. 1). If churches continue to provide supportive relationships, worship, make time for prayer, teach Scripture, and share the sacraments, they will provide one of the strongest benefits known to counter suicide.

Congregations and religious groups also function in providing support and integration. Sociologist Emile Durkheim theorized in 1897 that weak social bonds such as the "lack of connectedness were among the chief causes of suicidality" (Stone et al. 2017, p.27). Durkheim argued that "Individuals who were isolated from social life, who were not active participants in families, religious groups, or community organizations, were more prone to suicide" (Koenig 1998, 52). These ideas mirror modern social network theory and consistently show support for suicide rates in the United States and abroad (Koenig 1998, p. 53). The nineteenth-century concepts Durkheim expressed are considered scientifically valid today as social network theory (Koenig 1998). Congregations are relevant to combat suicide because they provide supportive and integrative communities.

\subsection{Reducing Suicidal Stigma through Acceptance and Action}

Reducing stigma requires congregations to practice their principles of faith and love. This is part of the human story, and in it, there is a role for congregations to share the love of God with all people. Love should be an outgrowth of every Christian congregation (Johnson 2017). "Yet," Lund warns, "too often Christian communities cause more harm and suffering by suggesting that mental illness is something shameful and somehow a sign of unfaithfulness and even sinfulness" (Lund 2014, p. 83). It is a tragedy when faith 
communities push shame and stigma, instead of healing and reconciliation, onto already wounded people (Lund 2014). Congregations must not behave or communicate in ways that would shame, frighten, or reject mental health consumers. If they do, then the church's actions create stigma and even more suffering for someone who needs compassionate care (Simpson 2013). Stigma is real. It pushes people away from church and from God. Congregations need to push back on any appearance of rejection or shame (Lund 2014). If a person is already contemplating suicide, then less than loving attitudes might push that person into even greater darkness. Stigma must stop within church communities because it goes against the grain of God.

Visiting someone at risk of suicide during or after a hospitalization can have a powerful impact. On this matter, the National Action Alliance for Suicide Prevention states the following:

The transition from inpatient to outpatient behavioral health care is a critical time for patients with a history of suicide risk and for the health care systems and providers who serve them. In the month after patients leave inpatient psychiatric care, their suicide death rate is 300 times higher (in the first week) and 200 times higher (in the first month) than the general population's (Chung et al. 2019). Their suicide risk remains high for up to three months after discharge (Olfson et al. 2016; Walter et al. 2019) and for some, their elevated risk endures after discharge. (National Action Alliance for Suicide Prevention 2019, p. 1)

This is a critical time where congregations could show love for and be present with someone who does not value his or her own life. Congregations likely have mental health consumers as members or attendees. One in five Americans has a mental health problem (Mason 2014, p. 34). This means "one in five members of your congregation may be at risk of suicide because of a mental health disorder" (Mason 2014, p. 34). Churches could make an effort to conduct in-person visits once a suicidal individual is discharged. As well, congregations should make hospital visits to mental health centers and behavioral health clinics to see members. They could coordinate a visit or send caring contacts like an email or a text message to a person during the first twenty-four hours after being discharged for support and strength (Motto and Bostrom 2001).

\subsection{Reducing Suicidal Stigma through Gatekeeping}

Clergy are ideally positioned to reduce stigma in Christian communities. They are the subject matter experts on religion and spirituality. Ideally, clergy are trained to know religious precepts and teach doctrine. The Bible specifically names the ability to teach as a characteristic to become a pastor (Titus 1:9, 1 Tim. 3:2). They are the chief teachers, educators, and examples for their flock. Clergy can provide the leadership necessary to share core values and beliefs. They can also step into the role of correcting misinformation when parishioners espouse outdated teaching on the subject of suicide. Perhaps the greatest benefit that clergy can provide is being present to hurting parishioners. In reality, clergy act as pastoral counselors for millions of Americans. Christian beliefs are especially influential in the United States, with $70.6 \%$ of the country identifying as Christian (Cooperman 2018). Research shows that "Religion and spirituality often play a vital role in healing, people experiencing mental health concerns often turn first to a faith leader" (American Psychiatric Association Foundation 2016, p. 2). Clergy should be viewed as mental health workers on the front line of battle with suicide because they help people combat suicide every day. Weaver identifies a study showing that a person with a "mental health diagnosis is more likely to seek assistance from clergy than from psychologists and psychiatrists combined" (Weaver 1998, p. 350). The frequent use of clergy should not be a surprise, given their availability, accessibility, and the high trust that Americans have in them (Weaver 1998). Clergy are in a good place for long-term relationships with individuals and their families. This enables clergy to observe changes in behavior that may indicate early signs of distress. Due to the high levels of trust and use, pastors, priests, and religious leaders can directly 
benefit the communities they serve. As spiritual leaders, clergy can focus on the humane and thoughtful treatment of others, especially those at risk of suicide.

Utilizing gatekeepers in a church can reduce suicide and point people to resources during a time of personal crisis. Burnette et al. identify gatekeeping as a suicide prevention model that teaches how to "identify individuals who may be at risk of suicide, provide immediate support, and refer them to an appropriate individual who is able to offer help" (Burnette et al. 2015, p. 1). This model relies on individual gatekeepers to monitor people for the signs and symptoms of suicide. Burnette et al. describe them as "individuals in a community who have face-to-face contact with large numbers of community members as part of their usual routine" (Burnette et al. 2015, p. 2). Gatekeeping is listed as a national best practice to reduce suicide. According to the U.S. Department of Health and Human Services Office of the Surgeon General and National Action Alliance for Suicide Prevention (HHS), gatekeeping is documented as a community best practice within the National Strategy for Suicide Prevention (U.S. Department of Health and Human Services (HHS) Office of the Surgeon General and National Action Alliance for Suicide Prevention (2012)) under several goals and objectives $(56,72,126,128)$. It is commonly used in educational, healthcare, medical, and military settings for suicide prevention (Burnette et al. 2015, p. 2). Most adults and adolescents can be trained as gatekeepers; it just takes time to select and train individual gatekeepers. Gatekeeping community models require agencies and organizations to pick a suicide prevention course or program to teach gatekeepers. Gatekeeper programs typically discuss education on suicide, common attitudes, beliefs, and opinions regarding suicide, how to identify warning signs, listening to people with thoughts of suicide, and referring them to a caring individual. The Suicide Prevention Resource Center (SPRC) identifies twenty-eight different gatekeeper programs available to use (Suicide Prevention Resource Center 2020, pp. 2-17). All of these programs can be tailored and adjusted to specific groups. The SPRC states, "Specific audiences for gatekeeper training include those who have regular contact with people who may be at increased risk for suicide, such as high school teachers and students; first responders; faith community leaders; and people who work with older adults" (Suicide Prevention Resource Center 2018, p. 1). All gatekeeper trainings teach the same concepts, but they often differ in their complexity, length, format, and target audience (Suicide Prevention Resource Center 2020, pp. 1-2).

Training people in gatekeeping endeavors is time well spent. "There is substantial evidence that training can increase both declarative and perceived knowledge about suicide. Those who receive gatekeeper training are generally better able to recognize warning signs of suicide and choose effective intervention strategies compared with those who have not received training" (Burnette et al. 2015, pp. 5-6). This is a significant reason why churches should adopt a gatekeeper model for leadership, staff, teachers, volunteers, and employees.

\section{Conclusions}

As the paper has outlined, the major traditions of Christianity forbid suicide based on the beliefs expressed in Scripture. Christians hold that people are made in the image of God. This unique status sets people apart from the rest of creation, ascribes value to all of humanity, and demands preservation. Scripture declares this sanctity of life and demands that people preserve it. Christianity discourages suicide because the act communicates that there is no answer for despair. This is the opposite of the love, grace, and compassion one finds in the message of Scripture.

Roman Catholics and Protestants view suicide differently. The Roman Catholic Church views suicide as a mortal sin that can eliminate a Christian's salvation. A person who willfully and knowingly chooses suicide is considered to be in a state of mortal sin, not a state of grace. Suicide can be viewed as an unforgivable sin if no repentance is made. Protestants view suicide as a sin, but they believe that no sin can erase a Christian's salvation. For them, suicide is not the unforgivable sin that separates a person from God. Those who die by suicide do not go to Hell because of the act. Protestants strongly 
object to this idea because it creates a transactional view of sin and forgiveness, one where forgiveness is earned or received by one's own meritorious acts. The idea of a Christian going to Hell because of suicide would mean that his or her salvation was a work undone by the act of suicide. Protestants reject this concept because it suggests that suicide somehow becomes stronger than the death and resurrection of Jesus Christ.

Funding: This research received no external funding.

Informed Consent Statement: Not applicable.

Conflicts of Interest: The author declares no conflict of interest.

\section{Notes}

1 Obviously, there are multiple views among Christians as well as non-Christians regarding the legal and/or moral justifications for taking a life, that is, killing someone. Without going into those views, suffice it to say that the majority view is that people should not die by suicide.

2 Historical and critical scholarship question the reliability of the Noahic stories, along with all of Genesis 1-11. Even if one questions their reliability, Noah is theologically instructive about canonical teachings in Scripture regarding moral decision making, for example, as related to matters of suicide.

3 Some interpreters refer to verses like this one in advocating lex talionis (Lat., "law of retaliation"), epitomized by the language of an "eye for an eye" (Exod. 21:24). Jesus challenged this logic, advocating neither retaliating nor fleeing but challenging injustice by non-violent means (Matt. 5:38-42). However, Christians disagree about whether he advocated pacifism or if Jesus (and Scripture) still permits just retaliation, including just war ethics. Regardless of retaliation, the Genesis 9:6 passage emphasizes the importance and value of human life.

\section{References}

Adeogun, Eno. 2017. Church Ends Ban on Full Christian Funerals for Suicides. Premier Christian News, July 11. Available online: https: // premierchristian.news/en/news/article/church-ends-ban-on-full-christian-funerals-for-suicides (accessed on 28 June 2021).

Alessi, Scott. 2014. Is Suicide a sin? Catholic Teaching on Suicide Hasn't Changed, but it has Become More Nuanced. U.S. Catholic, October 28. Available online: https:/ / uscatholic.org/articles/201410/is-suicide-a-sin/ (accessed on 15 August 2021).

American Psychiatric Association Foundation. 2016. Mental Health: A Guide for Faith Leaders. Arlington: American Psychiatric Association Foundation.

Augustine. 1887. City of God. From Nicene and Post-Nicene Fathers. First Series. Edited by Philip Schaff. Translated by Marcus Dods. Buffalo: Christian Literature Publishing Co., vol. 2. Revised and Edited for New Advent by Kevin Knight. Available online: http: / / www.newadvent.org/fathers/120101.htm (accessed on 12 October 2021).

Baltimore Catechism Number 3. 1891. Lesson 33-From the Fourth to the Seventh Commandment. Available online: http://www. baltimore-catechism.com/lesson33.htm (accessed on 28 June 2021).

Brand, Chad, Charles Draper, and Archie England, eds. 2003. Holman Illustrated Bible Dictionary. Nashville: Holman Bible Publishers.

Burnette, Crystal, Rajeev Ramchand, and Lynsay Ayer. 2015. Gatekeeper Training for Suicide Prevention: A Theoretical Model and Review of the Empirical Literature. Rand Health Quarterly 5: 1-20.

Campbell, Courtney S. 1992. Religious Ethics and Active Euthanasia in a Pluralistic Society. Kennedy Institute of Ethics Journal 2: 253-77. [CrossRef] [PubMed]

Catechism of the Catholic Church. 2019. 2nd ed.Washington, DC: United States Catholic Conference.

Cerel, Julie, Margaret M. Brown, Myfanwy Maple, Michael Singleton, Judy van de Venne, Melinda Moore, and Chris Flaherty. 2018. How Many People Are Exposed to Suicide? Not Six. Suicide \& Life-Threatening Behavior 49: 529-34. [CrossRef]

Chung, Daniel, Dusan Hadzi-Pavlovic, Maggie Wang, Sascha Swaraj, Mark Olfson, and Matthew Large. 2019. Meta-analysis of suicide rates in the first week and the first month after psychiatric hospitalisation. BMJ Open 9: e023883. [CrossRef] [PubMed]

Clemons, James T. 1990. What Does the Bible Say about Suicide? Minneapolis: Augsburg Fortress.

Closson, David. 2016. What Does It Mean to Be Made in God's Image? The Ethics \& Religious Liberty Commission of the Southern Baptist Convention. May 4. Available online: https:/ / erlc.com/resource-library/articles/what-does-it-mean-to-be-made-ingods-image (accessed on 28 June 2021).

Cooley, Dennis R. 2020. Was Jesus an Assisted Suicide? Ethics, Medicine, and Public Health 14: 100514. [CrossRef]

Cooperman, Alan. 2018. When Americans Say They Believe in God, What Do They Mean? Washington, DC: Pew Research Center.

Croy, N. Clayton. 2003. “To Die Is Gain” (Philippians 1: 19-26): Does Paul Contemplate Suicide? Journal of Biblical Literature 122: 517-31. [CrossRef]

Drapeau, Christopher W., and John L. McIntosh. 2020. U.S.A. Suicide: 2019 Official Final Data. Washington, DC: American Association of Suicidology, December 23, Available online: http:/ / www.suicidology.org/facts-and-statistics / (accessed on 28 July 2021).

Hauerwas, Stanley. 1998. The Morality of Suicide: Issues and Options, by J. P. Moreland. In Suicide: A Christian Response. Edited by Timothy J. Demy and Gary P. Stewart. Grand Rapids: Kregel Publications, p. 190. 
Howsepian, Al A. 1998. Some Reservations about Suicide. In Suicide: A Christian Response. Edited by Timothy J. Demy and Gary P. Stewart. Grand Rapids: Kregel Publications, p. 300.

Hsu, Albert. 2017. In The Truth about Suicide, by Morgan Lee. Christianity Today, October 20. Available online: https:// www.christianitytoday.com/ct/2017/november/suicide-americans-taking-their-own-lives-church-al-hsu.html (accessed on 28 July 2021).

Idler, Ellen, and Linda George. 1998. What Sociology Can Help Us Understand about Religion and Mental Health. In Handbook of Religion and Mental Health. Edited by Harold G. Koenig. San Diego: Academic Press, p. 53.

Johnson, Eric L. 2017. God and Soul Care: The Therapeutic Resources of the Christian Faith. Downers Grove: IVP Academic.

Kaplan, Kalman J., and Paul Cantz. 2017. Biblical Psychotherapy: Reclaiming Scriptural Narratives for Positive Psychology and Suicide Prevention. Lanham: Lexington Books.

Kaplan, Kalman J., and Matthew B. Schwartz. 2008. A Psychology of Hope: A Biblical Response to Tragedy and Suicide. Grand Rapids: Eerdmans Publishing Co.

Keener, Craig S. 1993. The IVP Bible Background Commentary: New Testament. Downers Grove: InterVarsity Press.

Kehoe, Nancy. 1998. Religion and Mental Health from the Catholic Perspective. In Handbook of Religion and Mental Health. Edited by Harold G. Koenig. San Diego: Academic Press.

Koenig, Harold G. 2012. Religion, Spirituality, and Health: The Research and Clinical Implications. ISRN Psychiatry 2012: 278730. [CrossRef] [PubMed]

Koenig, Harold G., ed. 1998. Handbook of Religion and Mental Health. San Diego: Academic Press.

Lester, David. 2017. Does Religiosity Predict Suicidal Behavior? Religions 8: 238. [CrossRef]

Lund, Sarah Griffith. 2014. Blessed Are the Crazy: Breaking the Silence about Mental Illness, Family, and Church. Saint Louis: Chalice Press.

Mason, Karen. 2014. Preventing Suicide: A Handbook for Pastors, Chaplains and Pastoral Counselors. Downers Grove: IVP Books.

Mason, Karen. 2015. Developing a Christian theology of suicide. Africanus Journal 7: 5-14.

McKnight, Scot. 2007. A Community Called Atonement. Nashville: Abingdon Press.

Merrill, Eugene H. 1998. Suicide and the Concept of Death in the Old Testament. In Suicide: A Christian Response. Edited by Timothy J. Demy and Gary P. Stewart. Grand Rapids: Kregel Publications, pp. 315-26.

Motto, Jerome A., and Alan G. Bostrom. 2001. A Randomized Controlled Trial of Postcrisis Suicide Prevention. Psychiatric Services 52: 828-33. [CrossRef] [PubMed]

National Action Alliance for Suicide Prevention. 2019. Best Practices in Care Transitions for Individuals with Suicide Risk: Inpatient Care to Outpatient Care. Washington, DC: Education Development Center, Inc.

Noble, Alan. 2021. You Are Not Your Own: Belonging to God in an Inhuman World. Downers Grove: Intervarsity Press.

Oden, Thomas C. 2001a. Life in the Spirit. Systematic Theology: Volume Three. Peabody: Prince Press.

Oden, Thomas C. 2001b. The Living God. Systematic Theology: Volume One. Peabody: Prince Press.

O'Mathuna, Donal P. 1998. But the Bible Doesn't Say They Were Wrong to Commit Suicide Does It? In Suicide: A Christian Response. Edited by Timothy J. Demy and Gary P. Stewart. Grand Rapids: Kregel Publications, pp. 349-368.

Olfson, Mark, Melanie Wall, Shuai Wang, Stephen Crystal, Shang-Min Liu, Tobias Gerhard, and Carlos Blanco. 2016. Short-term suicide risk after psychiatric hospital discharge. Journal of the American Medical Association Psychiatry 73: 1119-1126. [CrossRef] [PubMed]

Pope, Charles. 2018. Salutary Repentance. Our Sunday Visitor News, December 17. Available online: https:/ /www.osvnews.com/2018 /12/17/salutary-repentance/ (accessed on 28 July 2021).

Post, Stephen. 1998. Ethics, Religion, and Mental Health. In Handbook of Religion and Mental Health. Edited by Harold G. Koenig. San Diego: Academic Press.

Ramsay, Richard F., Bryan L. Tanney, William A. Lang, and Tarie Kinzel. 2004. Suicide Intervention Handbook, 10th ed. Calgary: Living Works. Sheldrake, Philip. 2007. A Brief History of Spirituality. Oxford: Blackwell Publishing.

Simpson, Amy. 2013. Troubled Minds: Mental Illness and the Church's Mission. Downers Grove: IVP Books.

Stack, Steven. 2018. Religious Activities and Suicide Prevention: A Gender Specific Analysis. Religions 9: 127. [CrossRef]

Stone, Deb M., Kristin M. Holland, Bradford N. Bartholow, Alex E. Crosby, Shane P. Davis, and Natalie Wilkins. 2017. Preventing Suicide: A Technical Package of Policies, Programs, and Practices. Atlanta: National Center for Injury Prevention and Control, Centers for Disease Control and Prevention.

Strong, James. 1996. Strong's Exhaustive Concordance of the Bible. Nashville: Thomas Nelson Publishers.

Suicide Prevention Resource Center. 2018. Choosing a Suicide Prevention Gatekeeper Training Program-A Comparison Table. Waltham: Education Development Center, Inc.

Suicide Prevention Resource Center. 2020. Selecting and Implementing a Gatekeeper Training. Waltham: Education Development Center, Inc.

U.S. Department of Health and Human Services (HHS) Office of the Surgeon General and National Action Alliance for Suicide Prevention. 2012. National Strategy for Suicide Prevention: Goals and Objectives for Action. Washington, DC: HHS.

Van Hooff, Anton J. L. 1990. A Longer Life for 'Suicide': When Was the Latin Word for Self-murderer Invented? Romanische Forschungen 102: 255-59. Available online: http:/ / www.jstor.org/stable/27940086 (accessed on 28 July 2021).

Van Hooff, Anton J. L. 2000. A Historical Perspective on Suicide. In Comprehensive Textbook in Suicidology. Edited by Ronald W. Maris, Bruce Michael Bongar, Morton M. Silverman and Alan L. Berman. New York: The Guilford Press, pp. 96-126. 
Walter, Florian, Matthew J. Carr, Pearl LH Mok, Sussie Antonsen, Carsten B. Pedersen, Louis Appleby, Seena Fazel, Jenny Shaw, and Roger T. Webb. 2019. Multiple adverse outcomes following first discharge from inpatient psychiatric care: A national cohort study. Lancet Psychiatry 6: 582-589. [CrossRef]

Weaver, Andrew. 1998. Mental Health Professionals Working with Religious Leaders. In Handbook of Religion and Mental Health. Edited by Harold G. Koenig. San Diego: Academic Press.

Winslow, Forbes. 1972. The Anatomy of Suicide. Boston: Milford House.

World Health Organization. 2014. Preventing Suicide: A Global Imperative. Geneva: WHO Press. Mental Health and Substance Use, August 17, Available online: https:/ / www.who.int/publications/i/item/preventing-suicide-a-global-imperative (accessed on 28 July 2021).

World Health Organization. 2021. Suicide Worldwide in 2019: Global Health Estimates. Geneva: WHO Press, June 16, Available online: https:/ / www.who.int/publications/i/item/9789240026643 (accessed on 28 July 2021).

Wu, Andrew, Jing-Yu Wang, and Cun-Xian Jia. 2015. Religion and Completed Suicide: A Meta-Analysis. PLoS ONE 10 : e0131715. [CrossRef] [PubMed] 